Vol. 6(5), pp. 57-63, May 2014

DOI: $10.5897 /$ J PBC S2013.0415

Artic le Number: E719DA744946

ISSN 2006-9758

Copyright (C2014

Author(s) retain the copyright of this artic le

http:// www.academic joumals.org/IPBCS
Journal of Plant Breeding and Crop

Science

\title{
Genetics of yield and some yield contributing traits in Upland cotton (Gossypium hirsutum L.)
}

\author{
Amir Latif ${ }^{1 *}$, Tanweer Ahmad ${ }^{2}$, Sikandar Hayat ${ }^{1}$, Ghulam Sarwar ${ }^{1}$, M. Zahid Ehsan ${ }^{3}$, \\ Muzaffar Raza ${ }^{1}$, Muhammad Sarwer ${ }^{1}$ and Iftikhar Ahmad Khan ${ }^{2}$ \\ ${ }^{1}$ Ayub Agricultural Research Institute, Faisalabad, Pakistan. \\ ${ }^{2}$ University of Agriculture, Faisalabad, Pakistan. \\ ${ }^{3}$ King Abdul Aziz University, Saudia Arabia.
}

Received 9 October, 2013; Accepted 24 February, 2014

\begin{abstract}
Inheritance, general combining ability and specific combining ability were studied using four parents: FH-901, NIAB-Karishma, CIM-496 and MS-84 for different plant traits in Upland cotton (Gossypium hirsutum L.). Mean values of all genotypes were significantly different from each other for all the traits studied. Epistasis was not found to be involved in any of the traits. The inheritance of all the traits was controlled by additive type of gene action with partial dominance except seed cotton yield that was controlled by over-dominance type of gene action. It was further noticed that the parent MS-84 was best general combiner for the traits like plant height, number of monopodial branches and number of bolls. The cross MS-84 $\times$ NIAB-Karishma showed greater specific combining ability for plant height, number of monopodial branches and number of sympodial branches.
\end{abstract}

Key words: Inheritance, additive-dominance model, over-dominance, combining ability.

\section{INTRODUCTION}

Cotton (Gossypium hirsutum L.) is a major cash crop of Pakistan as well as in the world. It contributes $7.8 \%$ to value added in agriculture and about $1.6 \%$ in gross domestic product (GDP) of the country. The area in the year 2011 to 2012 under this crop was 2.83 million ha and the production was 13.6 million bales. Cotton provides raw material for the textile industry and is a major source of foreign exchange earnings of the country. Oil extracted from cotton seed is edible and its seed cake is also a rich feed supplement for milch animals. Multi-use of this crop has made it important for agricultural industry (Anonymous, 2012).

Inheritance pattern of different traits in crop plants is very complex. Additive-dominance model as reported by Hayman (1954) is an efficient method to study the inheritance pattern of quantitatively inherited traits.

Inheritance studies have a key role in the crop improvement programs. After acquainted with the knowledge of inheritance of certain agronomic traits the selection of suitable parents for a specific breeding program becomes easy and efficient. Most of the traits in Upland cotton show the same complex quantitative

*Correspond ing author. E-mail: amipbg05@gma il.com Author(s) agree that this artic le remain permanently open access under the terms of the Creative Commons Attribution Lic ense 4.0 Intemational License 
pattern of inheritance. Therefore, a full diallel analysis of four cotton parents has been performed to study the inheritance of different plant traits in this crop. Upland cotton (G. hirsutum L.) belongs to family Malvaceae and is tetraploid $(2 n=4 x=52)$ by nature. $G$. hirsutum and other species viz. Gossypium barbadense, Gossypium arboreum and Gossypium herbaceum produce spinnable fiber out of 50 species of genus Gossypium (Brubaker et al., 1999).

Cotton improvement can be accomplished by favorable combination of genes in cotton varieties through hybridization and study of inheritance of different yield contributing and fiber quality traits. For this purpose inheritance study of different plant traits like plant height, number of monopodial branches, number of sympodial branches, number of bolls, boll weight and seed cotton yield has been carried out to understand the genetic behavior of these traits in Upland cotton. Previous studies showed different results about the inheritance of these traits. Ahmad et al. (2003) found that an additive type of gene action was responsible for controlling the inheritance of plant height, number of sympodia, boll number and yield of seed cotton. Saravanan et al. (2003) explored that over-dominance type of gene action was involved in case of boll number, seed number per boll, plant height and yield of seed cotton. Kumari and Chaundeswari (2005) observed additive type of gene action involved in the inheritance of yield of seed cotton while non-additive type of gene action was responsible for number of monopodial branches. Both additive and nonadditive type of gene action was involved in the phenotypic expression of plant height, number of sympodial branches and boll weight. Inheritance of seed cotton yield is controlled by additive type of gene action (Aguiar et al., 2007). Kiani et al. (2007) observed an important role of additive gene effects in the inheritance of monopodial branches. Both additive and non-additive components of genetic variances were important in the inheritance of yield, boll number, boll weight and plant height. However, non-additive type of gene action was observed for sympodial branches. Abbass et al. (2008) studied the characters like number of monopodial branches, number of sympodial branches, boll weight and yield of seed cotton and found the involvement of additive type of gene action with partial dominance. Overdominance type of gene action was involved in the inheritance of number of bolls and boll weight while partial dominance in case of yield of seed cotton (Hussain et al., 2009). Singh et al. (2010) analyzed that inheritance of the characters like yield of seed cotton and boll weight was controlled by additive type of gene action. Additive type of gene action was observed in the inheritance of number of bolls per plant and boll weight (Lu and Myers, 2011).

The main objective of this study was to explore the nature of gene action involved in the inheritance of various traits, general combing ability, and specific combining ability. This work will help cotton breeders to choose suitable parents for hybridization in their future breeding programs.

\section{MATERIALS AND METHODS}

\section{Glasshouse experiment}

The experiment was designed in a $4 \times 4$ diallel fashion. The seed of four parents namely NIAB-Karishma, CIM-496, MS-84 and FH-901 was provided by the Department of Plant Breeding and Genetics, University of Agriculture, Faisalabad (UAF) situated at $31.26 \mathrm{~N}$ and $73.06 \mathrm{E}$, with an elevation of $184 \mathrm{~m}$ above sea level. These four parents were sown in pots placed in glasshouse of the Department of Plant Breeding and Genetics, UAF under controlled conditions in October, 2010.

All standard agronomic practices were performed from sowing to maturity to maintain health of the plants. At the time of flowering, these four parents were crossed in all possible combinations (Diallel fashion) to obtain 6 direct crosses, 6 reciprocals and 4 selfs.

\section{Field experiment}

Seed of all these crosses $\left(F_{1} s\right)$ and selfs was sown in the field in triplicate randomized complete block design in June, 2011. There were total of 48 entries in the experiment, 16 in each replication. There were 10 plants in a row of each genotype at $30 \mathrm{~cm}$ plant to plant and $75 \mathrm{~cm}$ row to row distance. At maturity data regarding plant height $(\mathrm{cm})$, number of monopodial branches, number of sympodial branches, number of bolls, boll weight $(\mathrm{g})$ and seed cotton yield $(\mathrm{g})$ were recorded from 5 guarded plants in each entry for different plant.

\section{Statistical analysis of the data}

Analysis of variance (ANOVA) by Steel et al. (1997) and genetic analysis using additive-dominance model as proposed by Hayman (1954) were performed. Regression coefficients (b) were calculated for each trait and level of its significance was tested using scaling test (t-test). Graphs were plotted between variances and covariances for all the traits studied. General rules of understanding the inheritance pattern from the graph are given as follows:

1) If the regression line intercepts the $\mathrm{Wr}$ axis at origin (zero intercept) then there is complete dominance.

2) If the regression line intercepts the $\mathrm{Wr}$ axis above origin (positive intercept) then there is partial dominance.

3) If the regression line intercepts the $\mathrm{Wr}$ axis below origin (negative intercept) then it shows over-dominance.

The values of parabola limits for the four arrays were calculated and a free hand parabola limit was drawn on the $\mathrm{Vr} / \mathrm{Wr}$ graph after plotting Wrii values against respective Vri values. Then array points were plotted using array variance and covariance and these points were scattered within the parabola limit.

\section{RESULTS}

The results indicated highly significant differences among the genotypes for all the characters under study (Table 1). Results of the joint regression analysis exhibited that data were fit for all the traits which confirmed the adequacy of simple additive-dominance model (Table 2). For all the traits the non-allelic interaction (epistasis) was not observed as regression line did not deviate from unit 
Table 1. Mean square values for yield and yield components of different cotton genotypes.

\begin{tabular}{lccccccc}
\hline $\begin{array}{l}\text { Source of } \\
\text { variation }\end{array}$ & $\begin{array}{c}\text { Degree of } \\
\text { freedom }\end{array}$ & $\begin{array}{c}\text { Plant } \\
\text { height }\end{array}$ & $\begin{array}{c}\text { No. of monopodial } \\
\text { branches }\end{array}$ & $\begin{array}{c}\text { No. of sympodial } \\
\text { branches }\end{array}$ & $\begin{array}{c}\text { Number } \\
\text { of bolls }\end{array}$ & $\begin{array}{c}\text { Boll } \\
\text { weight }\end{array}$ & $\begin{array}{c}\text { Seed } \\
\text { cotton yield }\end{array}$ \\
\hline Replications & 2 & 9.81 & 0.076 & 1.261 & 0.615 & 0.007 & 50.931 \\
Genotypes & 15 & $43.30^{\star *}$ & $0.194^{\star *}$ & $1.705^{\star *}$ & $1.682^{\star *}$ & $0.093^{\star *}$ & $122.517^{\star *}$ \\
Error & 30 & 3.02 & 0.058 & 0.409 & 0.271 & 0.031 & 20.763 \\
\hline
\end{tabular}

*, **: Significant at 5 and $1 \%$ level of probability, respectively.

Table 2. Results of joint regression analysis of six traits of cotton plant.

\begin{tabular}{lcccccc}
\hline $\begin{array}{l}\text { Regression } \\
\text { Coefficient }\end{array}$ & $\begin{array}{c}\text { Plant } \\
\text { height }\end{array}$ & $\begin{array}{c}\text { No. of monopodial } \\
\text { branches }\end{array}$ & $\begin{array}{c}\text { No. of sympodial } \\
\text { branches }\end{array}$ & $\begin{array}{c}\text { Number of } \\
\text { bolls }\end{array}$ & $\begin{array}{c}\text { Boll } \\
\text { weight }\end{array}$ & $\begin{array}{c}\text { Seed cotton } \\
\text { yield }\end{array}$ \\
\hline b value & $0.99 \pm 0.01$ & $0.98 \pm 0.048$ & $0.94 \pm 0.078$ & $0.96 \pm 0.21$ & $1.09 \pm 0.03$ & $1.01 \pm 0.14$ \\
Conclusion & Fit & Fit & Fit & Fit & Fit & Fit \\
\hline
\end{tabular}

As the regression coefficient (b) value of all the traits deviated significantly from zero but not from unity therefore, the data of all the traits were fit for genetic analysis.

slope (Figures 1 to 6 ). In joint regression analysis the regression coefficient (b value) must deviate significantly from zero but not from unity for the data to be adequate for simple additive-dominance model developed by Hayman (1954). The graphs were plotted between variances $(\mathrm{Vr})$ and covariances $(\mathrm{Wr})$ of all the traits to explore the gene action involved in the inheritance of these traits. The $\mathrm{Vr} / \mathrm{Wr}$ graphs (Figures 1 to 5) showed that regression line in each graph intercepted the Wr-axis above the origin which indicated an additive type of gene action with partial dominance involved in the phenotypic expression of plant height, number of monopodial branches, number of sympodial branches, number of bolls and boll weight. Whereas, the graphical representation of $\mathrm{Vr} / \mathrm{Wr}$ graph for seed cotton yield (Figure 6) revealed that regression line intercepted the $\mathrm{Wr}$-axis below the origin which indicated non-additive type of gene action involved in the inheritance of seed cotton yield.

The parent MS-84 being nearest to the origin possessed maximum dominant genes, while CIM-496 being away had maximum recessive genes for plant height as revealed by their relative positions on the regression line (Figure 1). The average performance of the parents and their crosses (Table 3 ) indicated that variety MS-84 was best general combiner for plant height as it scored the highest array mean (94.94) for plant height. The best specific combining ability for this trait was exhibited by MS-84 $\times$ NIAB-Karishma scoring highest value of 95.58 .

The relative positions of the array points on the regression line revealed that MS-84 being nearest to the origin possessed maximum dominant genes while NIABKarishma being away had the maximum recessive genes for number of monopodial branches (Figure 2). The diallel mean table (Table 3) indicated that parent NIABKarishma with the highest array mean value of 2.03 proved best general combiner among four cotton varieties under study and cross NIAB-Karishma $\times$ MS-84 has highest specific combining ability for number of monopodial branches as it possessed maximum value of 1.97 for this trait.

The $\mathrm{Vr} / \mathrm{Wr}$ graph for number of sympodial branches (Figure 3) exhibited that MS-84 being nearest to the origin possessed maximum dominant genes while $\mathrm{FH}-901$ being away had the maximum recessive genes. The data (Table 3) showed that the parent MS-84 with highest array mean was best general combiner and cross MS-84 $\times$ NIAB-Karishma having maximum value of 13.63 proved the best specific combiner for the trait.

Distribution of array points on the regression line shown in the $\mathrm{Vr} / \mathrm{Wr}$ graph for number of bolls (Figure 4) indicated that the variety CIM-496 being close to origin possessed the maximum number of dominant genes and MS-84 being farthest from the origin had maximum number of recessive genes. Diallel mean table (Table 3) for number of bolls revealed highest array mean 16.92 for this trait indicating that the parent MS-84 was good general combiner, while cross MS-84 $\times$ FH-901 possessed highest value of 16.88 showing the best specific combining ability effects for the character.

The figure of $\mathrm{Vr} / \mathrm{Wr}$ graph for boll weight (Figure 5) showed that the variety CIM-496 possessed maximum dominant genes because it was nearest to the origin as exhibited by its relevant position on the regression line while NIAB-Karishma had maximum recessive genes due to its reverse position. The data of diallel mean table (Table 3) showed that the variety CIM-496 with the maximum array mean (2.83) had highest general combining ability and cross $\mathrm{CIM}-496 \times \mathrm{FH}-901$ possessed 


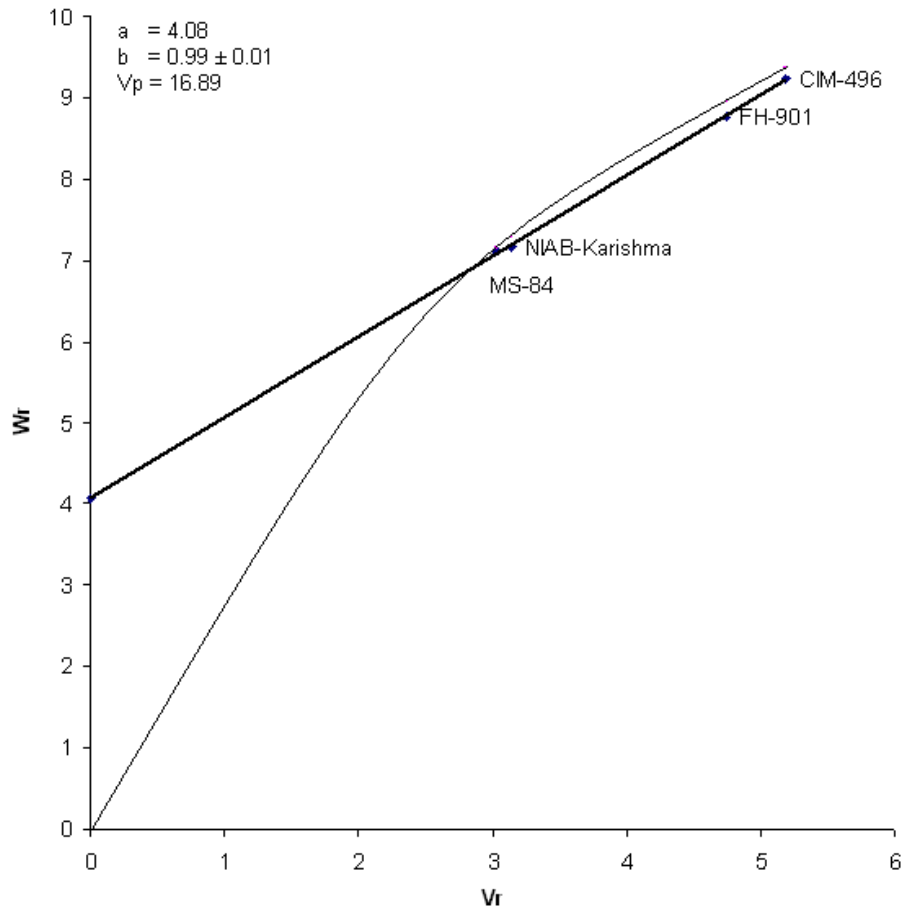

Figure 1. Vr/Wr graph for plant height.

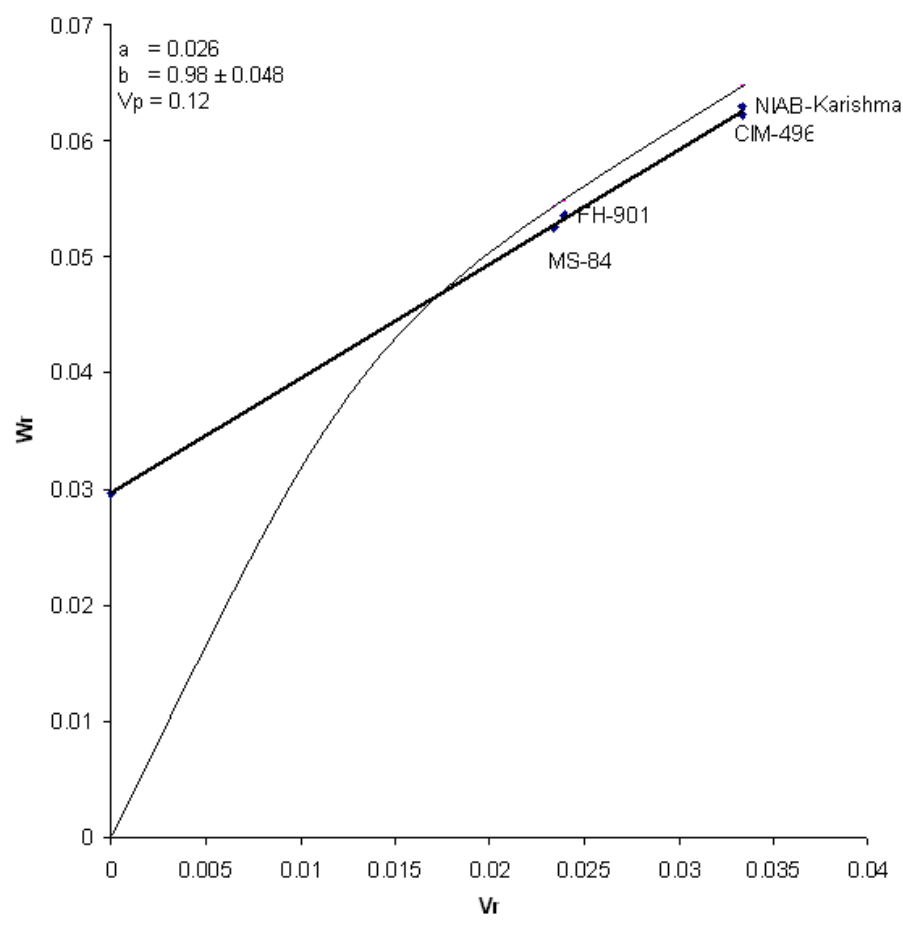

Figure 2. $\mathrm{Vr} / \mathrm{Wr}$ graph for number of monopodial branches.

maximum value of 2.88 proving best specific combiner for boll weight.

The relative positions of array points on the regression

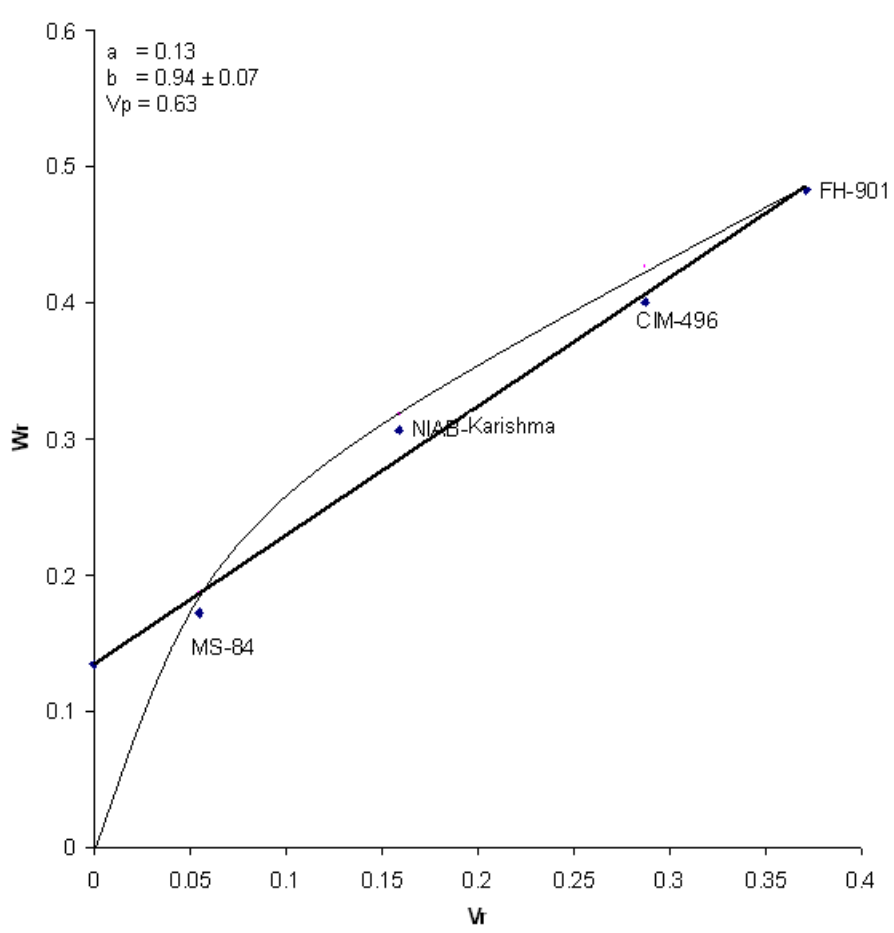

Figure 3. $\mathrm{Vr} / \mathrm{Wr}$ graph for number of sympodial branches.

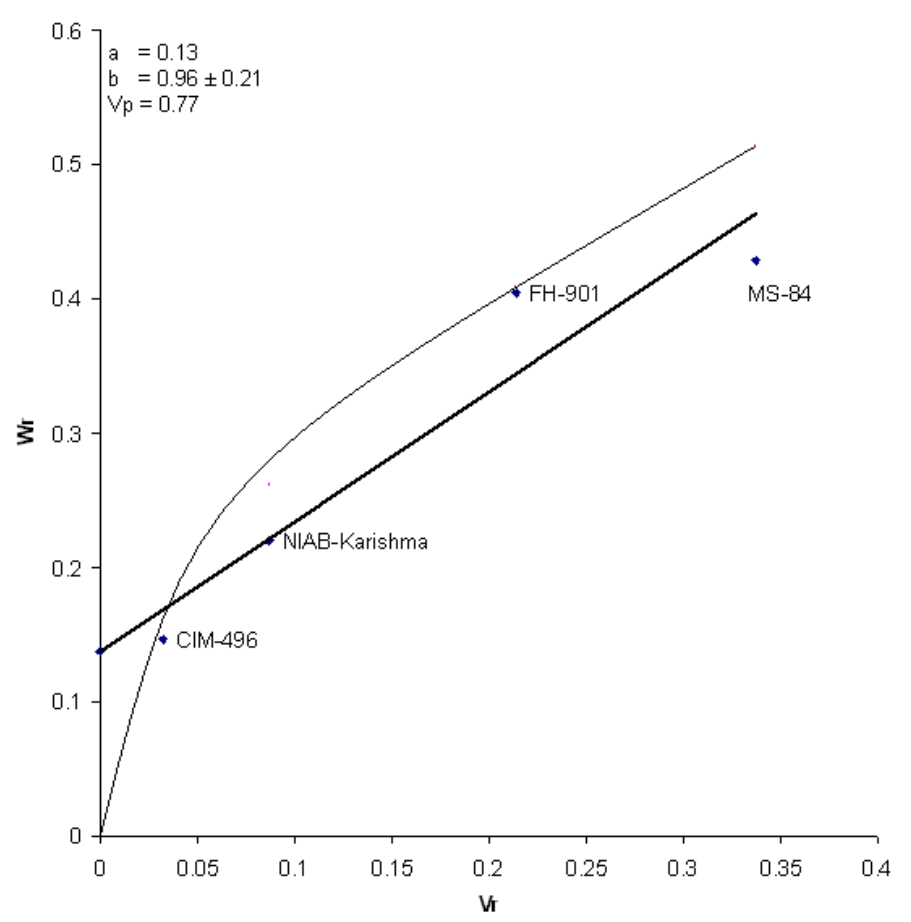

Figure 4. Vr/Wr graph for number of bolls.

line revealed that variety NIAB-Karishma being in close proximity to the origin, possessed the maximum number of dominant genes for seed cotton yield while FH-901 had 


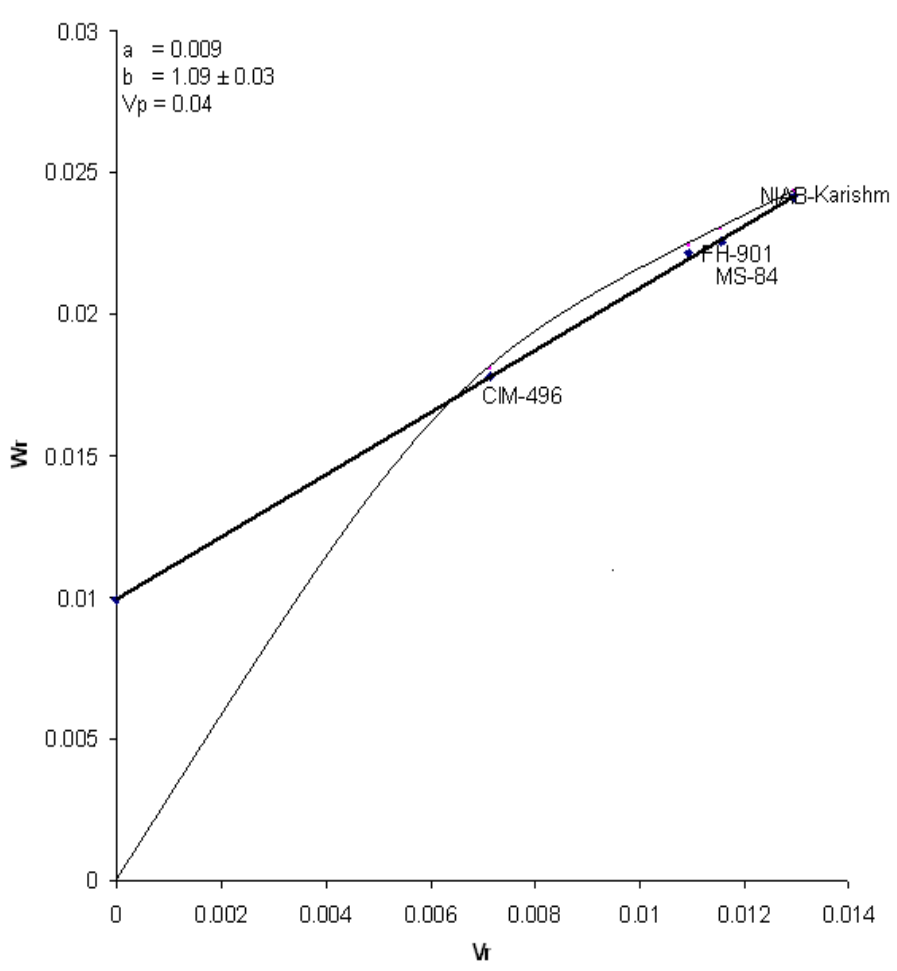

Figure 5. $\mathrm{Vr} / \mathrm{Wr}$ graph for boll weight.

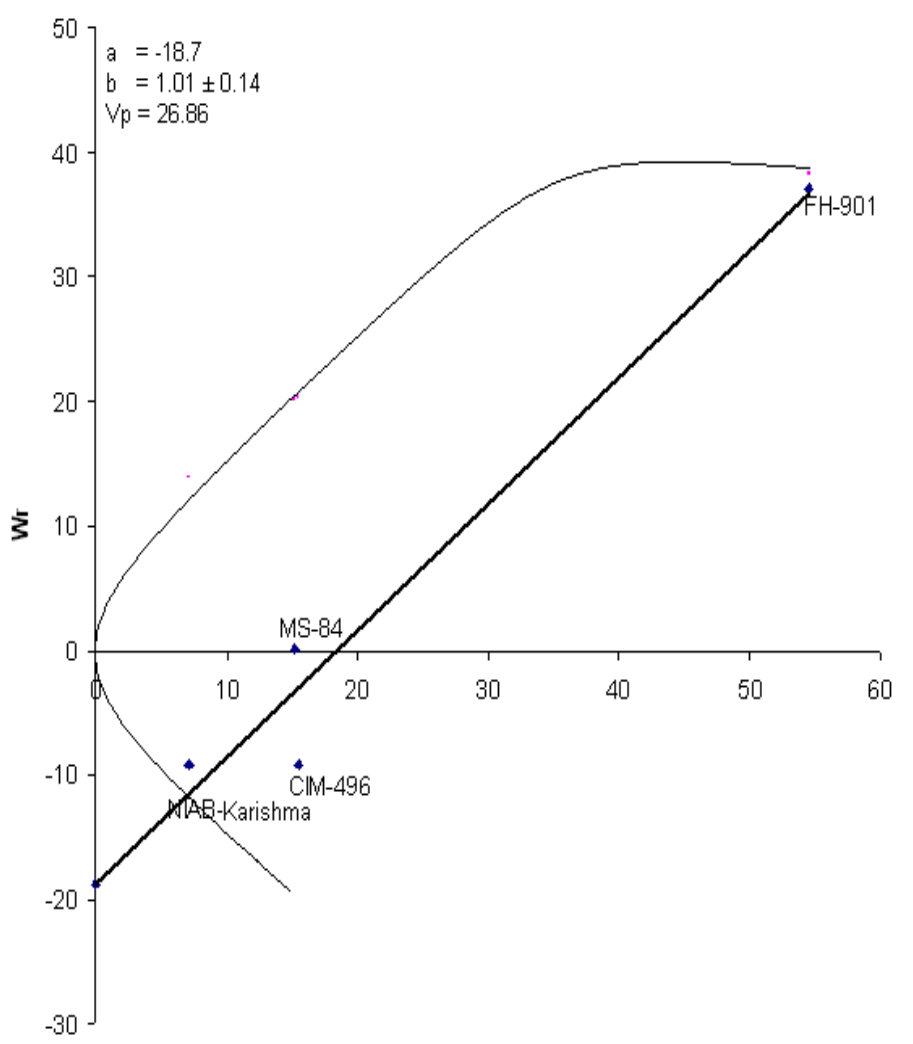

V r

Figure 6. Vr/Wr graph for seed cotton yield. maximum number of recessive genes for this trait as it occupied the farthest position from the origin (Figure 6). The variety NIAB-Karishma scoring the maximum array mean (38.82) proved to be the best general combiner and it made the best combination with $\mathrm{FH}-901$ as its value in this specific cross was 41.23 for this character (Table 3 ).

\section{DISCUSSION}

Simple selection is suitable for improvement of the traits like plant height, number of monopodial branches, number of sympodial branches, number of bolls and boll weight because inheritance of all these traits were controlled by additive type of gene action with partial dominance. These results were also supported by Banumathy and Patil (2000), Ahmad et al. (2003), Neelima et al. (2004), Azhar and Khan (2005), Ahmad et al. (2006), Abbass et al. (2008), Kumboh et al. (2008), Ali et al. (2009), Khan et al. (2009a), Zangi et al. (2010) and Singh et al. (2010). However, different results were reported by Zia-ul-Islam et al. (2001), Saravanan et al. (2003), Kumari and Chaundeswari (2005), Iqbal et al. (2003), Inam-ul-Haq and Azhar (2004) and Khan et al. (2009b). These different results might be due to using different genotypes and experiments conducted in different environments.

General combining ability effects showed that parent MS-84 can be used in varietal improvement programs to enhance the traits like plant height, number of sympodial branches and number of bolls, being a best general combiner for these traits as it has the highest array means 94.94, 13.27 and 16.92 for these traits, respectively. The parent NIAB-Karishma can be selected for improvement of number of monopodial branches with the highest array mean value of 2.03 for this trait. However, specific combining ability effects shows that the parent MS-84 in its cross with NIAB-Krishma has relatively high values for plant height, number of monopodial branches and number of sympodial branches but these values of crosses do not remarkably differ from parent values therefore there is no need to consider this cross for hybrid development for these traits.

However, the trait seed cotton yield can be improved through hybrid breeding as its inheritance was controlled by over-dominance type of gene action. Similar results were also found by Inam-ul-Haq and Azhar (2004), Ali et al. (2009) and Khan et al. (2009b). The cross combination NIAB-Karishma $\times$ FH-901 can be developed into a hybrid having high seed cotton yield as its value in this specific cross was 41.23 for this character.

\section{Conclusion}

From the findings of this study, it can be inferred that additive type of gene action was involved in the 
Table 3. $4 \times 4$ Diallel mean table for six plant traits in Upland cotton.

\begin{tabular}{|c|c|c|c|c|c|c|c|}
\hline \multicolumn{2}{|c|}{ Genotypes crossed } & \multirow{2}{*}{$\begin{array}{c}\begin{array}{c}\text { Plant } \\
\text { height }\end{array} \\
88.7\end{array}$} & \multirow{2}{*}{$\begin{array}{c}\text { No. of monopodial } \\
\text { branches }\end{array}$} & \multirow{2}{*}{$\begin{array}{c}\begin{array}{c}\text { No. of sympodial } \\
\text { branches }\end{array} \\
12.37\end{array}$} & \multirow{2}{*}{$\begin{array}{c}\begin{array}{c}\text { No. of } \\
\text { bolls }\end{array} \\
15.83\end{array}$} & \multirow{2}{*}{$\begin{array}{c}\begin{array}{c}\text { Boll } \\
\text { weight }\end{array} \\
2.91\end{array}$} & \multirow{2}{*}{$\begin{array}{c}\begin{array}{c}\text { Seed cotton } \\
\text { yield }\end{array} \\
25.24\end{array}$} \\
\hline \multirow{4}{*}{$\mathrm{FH}-901$} & FH-901 & & & & & & \\
\hline & NIAB-Karishma & 92.2 & 2.07 & 12.95 & 16.42 & 2.69 & 41.23 \\
\hline & CIM-496 & 89.53 & 1.7 & 11.88 & 16.03 & 2.88 & 40.49 \\
\hline & MS-84 & 93.32 & 1.85 & 13.25 & 16.88 & 2.77 & 34.58 \\
\hline \multirow{4}{*}{ NIAB-Karishma } & $\mathrm{FH}-901$ & 92.2 & 2.07 & 12.95 & 16.42 & 2.69 & 41.23 \\
\hline & NIAB-Karishma & 93.63 & 2.27 & 13.3 & 16.83 & 2.47 & 35.23 \\
\hline & CIM-496 & 91.6 & 1.83 & 12.47 & 16.22 & 2.72 & 38.38 \\
\hline & MS-84 & 95.58 & 1.97 & 13.32 & 16.78 & 2.58 & 40.43 \\
\hline \multirow{4}{*}{ CIM-496 } & $\mathrm{FH}-901$ & 89.53 & 1.7 & 11.88 & 16.03 & 2.88 & 40.49 \\
\hline & NIAB-Karishma & 91.6 & 1.83 & 12.47 & 16.22 & 2.72 & 38.38 \\
\hline & CIM-496 & 88.67 & 1.4 & 11.83 & 15.9 & 2.91 & 36.93 \\
\hline & MS-84 & 93.77 & 1.6 & 12.97 & 16.3 & 2.82 & 31.31 \\
\hline \multirow{4}{*}{ MS-84 } & $\mathrm{FH}-901$ & 93.32 & 1.85 & 13.25 & 16.88 & 2.77 & 34.58 \\
\hline & NIAB-Karishma & 95.58 & 1.97 & 13.32 & 16.78 & 2.58 & 40.43 \\
\hline & CIM-496 & 93.77 & 1.6 & 12.97 & 16.3 & 2.82 & 31.31 \\
\hline & MS-84 & 97.1 & 1.8 & 13.53 & 17.7 & 2.68 & 33.54 \\
\hline
\end{tabular}

inheritance of most of traits except seed cotton yield which was being controlled by over-dominance type of gene action. Further gene action was not complicated with non-allelic interaction. This information explains that the characters involving additive type of gene action can be improved through simple selection. The inheritance of seed cotton yield revealed some heterosis in the characters thus implying towards exploitation of such progenies in a breeding program where development of hybrid cotton is the ultimate objective.

\section{Conflict of Interests}

The author(s) have not declared any conflict of interests

\section{ACKNOWLEDGEMENT}

The research was funded by the United States Agency for International Development (USAID).

\section{REFERENCES}

Abbass A, Ali MA, Khan TM (2008). Studies on gene effects of seed cotton yield and its attributes in five American cotton cultivars. J. Agri. Soc. Sci. 04(4):147-152.

Aguiar PAd, Penna JCV, Freire EC, Melo LC (2007). Diallel analysis of upland cotton cultivars. Crop Breed. Appl. Biotechnol. 7:353-359. http://dx.doi.org/10.12702/1984-7033.v07n04a04

Ahmad S, IqbaL MZ, Ahmad S, Sadiq MA, Khan NI (2003). Genetic analysis of morphological characteristics and seed oil content of cotton (Gossypium hirsutum L.). Euphytica 129(2):183-191. http://dx.doi.org/10.1023/A:1021974901501

Ahmad HM, Kandhro MM, Laghari S, Abro S (2006). Heritability and genetic advance as selection indicators for improvement in cotton (Gossypium hirsutum L.). J. Biol. Sci. (1):96-99.

Ali MA, Abbas A, Younas M, Khan TM, Hassan HM (2009). Genetic basis of some quantitative traits in upland cotton (Gossypium hirsutum L.). Plant Omics J. 2(2):91-97.

Anonymous (2012). Economic survey of Pakistan. Ministry of Food and Agriculture. Government of Pakistan.

Azhar MT, Khan AA (2005). Combining ability analysis of seed cotton yield and its components in cotton (Gossypium hirsutum L.). Pak. J. Sci. Ind. Res. 48(5):358-361.

Banumathy S, Patil S (2000). Diallel analysis for seed cotton yield and its components in cotton. Ann. Plants Physiol. 14(1):56-61.

Brubaker CL, Bourland EM, Wendel JF (1999). The origin and domestication of cotton. In C.W. Smith and J.T. Cothren (ed.) Cotton: Origin, history, technology, and production. John Wiley and Sons, New York. pp. 3-31.

Hayman BI (1954). The theory and analysis of diallel crosses. Genetics 39:789-809. PMid:17247520 PMCid:PMC1209689

Hussain M, Azhar FM, Khan AA (2009). Genetics of inheritance and correlations of some morphological and yield contributing traits in upland cotton. Pak. J. Bot. 41(6):2975-2986.

Inam-ul-Haq, Azhar FM (2004). Genetic basis of varietal differences for seed cotton yield and its components in Gossypium hirsutum L. Int. J. Agric. Biol. 6(5):904-907.

Iqbal M, Chang MA, Iqbal MZ, Mahmood-ul-Hassan, Karim A, Ahmad S (2003). Breeding behaviour effects for yield, its components and fiber quality traits in intraspecific cross of cotton (Gossypium hirsutum L.). J. Biol. Sci. 3(4):451-459.

http://dx.doi.org/10.3923/jbs.2003.451.459

Khan NU, Hassan G, Marwat KB, Farhatullah, Kumbhar MB, Khan N, Parveen A, Aiman U, Khan MZ, Soomro ZA (2009a). Diallel analysis of some quantitative traits in Gossypium hirsutum L. Pak. J. Bot. 41(6):3009-3022.

Khan NU, Hassan G, Kumbhar MB, Marwat KB, Khan MA, Parveen A, Aiman U, Saeed M (2009b). Combining ability analysis to identify 
suitable parents for heterosis in seed cotton yield, its components and lint $\%$ in upland cotton. Ind. Crop. Prod. 29:108-115. http://dx.doi.org/10.1016/j.indcrop.2008.04.009

Kiani G, Nematzadeh GA, Kazemitabar SK, Shah OA (2007). Combining ability in cotton cultivars for agronomic traits. Int. J. Agric. Boil. 09(3):521-522.

Kumari SR, Chmundeswari N (2005). Studies on genetic variability, heritability and genetic advance in cotton (Gossypium hirsutum L.). Int. J. Res. Crops. 6(1):98-99.

Kumboh N, Baloch MJ, Kumbhar MB, Khanzada S, Jatoi WA (2008). Diallel analysis for estimating combining ability in upland cotton (Gossypium hirsutum L.). Pak. J. Agric. Eng. Vet. Sci. 24(1):27-33.

Lu H, Myers GO (2011). Combining abilities and inheritance of yield components in influential upland cotton varieties. Aust. J. Crop Sci. 5(4):384-390.

Neelima S, Reddy VC, Reddy AN (2004). Combining ability studies for yield and yield components in American cotton (Gossypium hirsutum L.). Ann. Agric. Biol. Res. 9(1):1-6.

Saravanan NA, Gopalan A, Sudhagar R (2003). Genetic analysis of quantitative characters in cotton (Gossypium spp.). Madras J. Agric. 90(4-6):236-238.

Singh S, Singh VV, Choudhary AD (2010). Combining ability estimates for oil content, yield components and fibre quality traits in cotton (Gossypium hirsutum L.) using an $8 \times 8$ diallel mating design. Trop. Subtrop. Agroecosyst. 12:161-166.
Steel RGD, Torri JH, Dickey DA (1997). Principles and procedures of statistics: A biometrical approach Singapore: 3rd Ed. McGraw Hill Book Co. Inc.

Zangi MR, Jaloder NB, Kazmitabar SK, Vafaei-Tabar M (2010). Cytoplasmic and combining ability effects on agro-morphological characters in intra and inter crosses of pima and upland cottons. Int. J. Agric. Biol. 2(1).

Zia-ul-Islam, Sadaqat HA, Khan FA (2001). Evaluation of some cotton strains for their combining ability in important genetic traits. Int. J. Agric. Biol. 3(4):409-410. 